\title{
EMPLOYEE'S PRODUCTIVITY IN AUTOMOBILE INDUSTRY: A REVIEW
}

\author{
Sachin Ahirwar \\ M. Tech Scholar, Department of Mechanical Engineering \\ BTIRT Sagar, Madhya Pradesh, India
}

\begin{abstract}
Training is aimed in improving the conduct and performance of workers. Worker commitment is the level of responsibility and association a worker has towards the organization and its qualities. The information required for the examination had been accumulated from both primary and secondary data. Every one of these exercises focus on progress of workers productivity. Convenient sampling is utilized and descriptive exploration is received. The center piece of the investigation lies in the analysis and interpretation. It was discovered that training has positive and critical effect on worker's productivity in Indian Automobile industry. Through this research we can build up a conceptual framework for future research that focuses around workers performance improvement. The research was lead for workers working in automobile industry with respect to effectiveness of the training programs in industries.
\end{abstract}

Keywords-Productivity, Performance, Training Strategies, Sample size, Data collection.

\section{INTRODUCTION}

We are living in a quick developing world with opportunities to develop and flourish. According to the ongoing report by The World Bank, India is set to rise as the world's fastest developing significant economy by 2016 in front of China [1]. Human asset is the existence blood of each organization. Just through great trained work force, an organization can accomplish its objectives. Workers are the most significant resource of each organization as they can represent the deciding moment an organization's notoriety and can unfavorably influence benefit. Employees frequently are liable for the incredible bulk of essential work to be done just as consumer loyalty and tie quality of items and services.

This competition has constrained every auto producers to upgrade their labor. To accomplish this objective employee training was given prime significance. In the Endeavor to accomplish greatness, the quantity and quality of training were continuing increasing. It is at this crossroads the need of analyzing the impact of training on worker's productivity in Automobile Industry emerged.

\author{
Akash Tomar \\ Asst. Prof., Department of Mechanical Engineering \\ BTIRT Sagar, Madhya Pradesh, India
}

This investigation is limited uniquely to the Automobile industry to make a top to bottom examination on the theme so a reasonable image can be cut out of these practices and sum it up in a later stage with point by point inputs.

Training is defined in various manners depending upon the context of reference. Training can be characterized as a "Systematic procedure of gaining information, skills, capacities, and the correct attitudes and practices to meet job necessities". [2]

Studies by Cole (1997) demonstrated training as a learning procedure which is planned for affecting knowledge and skills to empower the employees execute their work task better. Training can be defined as a learning movement which is coordinated towards the obtaining of explicit knowledge and skills with the end goal of an occupation or assignment.[2][3]

\section{OBJECTIVES OF THE RESEARCH}

1. To identified the viability of training strategies received by Automobile Industry dependent on selected demographics.

2. To study and recognize the connection between training and worker's productivity in Auto Mobile Industry.

3. To study the effect of training on worker's productivity in Automobile Industry

4. To look at the effect of training on worker's productivity Automobile Industry.

5. To create scale for measuring training and employee's productivity in Automobile Industry.

6. To study and develop model on successful training strategies to be adopted by Automobile Industry.

7. To study and identified the skill gap in Automobile Industry.

\section{REVIEW OF LITERATURE}

The Indian Automobile Industry is one of the fastest developing automobile enterprises on the world with a Compounded Annual Growth Rate (CAGR) of approximately $7 \%$ throughout the most recent couple of years. At present it is the eleventh biggest passenger vehicle manufacturer, fourth 


\section{International Journal of Engineering Applied Sciences and Technology, 2020 Vol. 5, Issue 8, ISSN No. 2455-2143, Pages 97-101 \\ Published Online December 2020 in IJEAST (http://www.ijeast.com)}

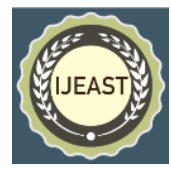

biggest commercial vehicle maker and the second biggest two wheeler producer on the world.

Cascio W.F. (1989), places training along these lines "The financial and technological patterns, the pace of advancement, change and improvement have been developing faster year-byyear and therefore, these are clear signals that preparation and improvement are significant that the two associations and individual partners must consider as very serious. [5]

Linda Maund (2001), in his book 'An Introduction to Human Resource Management, hypothesis and practice', expressed that "one of a supervisor's most significant occupations is to deal with the employee advancement of a worker which incorporates his/her self-awareness and profession development."[6]

Cole G. (2004), contended that, HR are the most unique asset of the assets at the removal of the organization and along these lines, the human resources should be given extensive consideration from management to empower this resources understand their maximum capacity $m$ their work. Consequently, management must address inspiration, authority, correspondence work rebuilding, installment frameworks and training and improvement.[7][8]

Monappa and Saiyadain (2008), define training as "the educating or learning exercises carried on for the main role of helping individuals from an organization to obtain and apply the information, aptitudes, capacities and mentalities required by that organization. It is the demonstration of expanding the information and aptitude of a employee for doing a particular work". Training subsequently should be seen by management of each organization as a drawn out interest in its human resources. [9]

Bates R. and Khasawneh (2005), defined Training move as the procedure an individual experiences to utilize data increased through training to straightforwardly improve work performance. [10]

In any case, training move isn't restricted to the subjective learning process itself yet incorporates the extra inward and outward components that sway the training procedure and eventually the degree of move and execution that occurs.

Kenneth M. York (2009), to maximize the effectiveness of training and development, organization should constantly assess their workers present training and development needs and distinguish training and development needs to get ready employees for their next position. This necessitates organization recognize that diverse employees will have various requirements and that these requirements will change after some time as these laborers proceed in their professions. [11]

Ashfaq F et al (2011), the investigation of relationship of the workers' training with execution is significant for the present supervisors in light of the fact that the modem business patterns requests more productivity, exactness and adequacy in less time and test and this can be accomplished distinctly through plan, advancement and organization of excellent training projects to the employees.[12]

Beam S (2012), states that "The all inclusive effective car authors will make their base in places which are high on productivity factor and limit usage and where fundamental upper hands of the business can be made and supported. It would likewise include center items and procedure innovation creation separated from keeping up beneficial human resources and award for cutting edge ability". Hole investigation is applied by firms, who are quick to bring their organization up to the global principles 48

Gupta S. and Bestrom R.P (2006) in their report named EndUser Training Methods: What We Know, need to Know found that it $\mathrm{s}$ one of the most unavoidable strategies for improving employees' presentation upgrading organization productivity in the work place. [14]

Budria (2008), in his paper considered the impact of professional training on productivity of 1621 specialists in the travel industry area firms utilizing a logic model. He discovered that after arrangement of training the laborers' productivity expanded significantly. $(\mathrm{r}=0.222)$. Also he analyses that training helped ladies insignificant than men members to improve their productivity and that informed male people show signs of improvement work after arrangement of training aptitudes." [13]

Sultana A et al. (2012), In this investigation Training practices of Telecommunication Sector in Pakistan were inspected to decide their effect on Employee Performance. Nor then again this examination 360, surveys had been appropriated among the workers cf five telecom organizations. Training is a key component for improved execution; it can build the degree of individual and hierarchical competency. It assists with accommodating the hole between what ought to occur and what's going on - between wanted targets or gauges and genuine degrees of work execution. Training need is any shortfall in employee exhibition, or potential execution which can be remedies by proper training. There are numerous methods of defeating lacks in human execution at work, and training is one of them. Training improves aptitudes, competency, capacity and at last worker execution and productivity in organization.[15]

Omole (2004) emphasized visit labor improvement includes giving learning and advancement openings, making training mediation and arranging, leading and assessing training programs. [16]

Nazimek J (2014), Exercise improves objective directed activity. This incorporates choosing, arranging and organizing activities, just as ignoring distracters and dealing with a few snippets of data immediately permitting hindrance and flexible thinking.[17] 


\section{International Journal of Engineering Applied Sciences and Technology, 2020 Vol. 5, Issue 8, ISSN No. 2455-2143, Pages 97-101 \\ Published Online December 2020 in IJEAST (http://www.ijeast.com)}

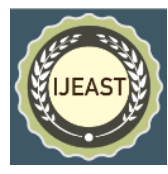

Ankita Shreeram (2011), talked with Deepak Kaistha, executive, PI groan consulting, about Just in time training. He said "With the openness and comfort of data accessible on the web, many would concur with me :cap as opposed to sitting though long periods of conventional homeroom training, clients can tap data through electronic instructional exercises, intelligent CD ROMs and different apparatuses to focus in on simply the information they have to tackle issues." [20]

\section{PURPOSE OF THE STUDY}

The motivation behind this study is to analyze the effect of training on employee's productivity in Automobile Industry. In this study, effect of training on employee's productivity in Automobile Industry was inspected and for the sake of detailed comparative investigation two heavy vehicle part manufacturing industries were chosen. Keeping in see the objective of the investigation, review of existing literature and hypothesis framed, there are five significant zones to look at in this research:

First region of research was the scientific and hypothetical study of the employee training and productivity in Automobile parts Industry. This study looked to inspect and identify a model to examine the employee training and productivity.

Second territory of exploration was the analytical and theoretical determination of the effect of training on worker's productivity.

The third region of research and the center of this examination were to make a similar investigation of the effect of training on employee's productivity.

In the fourth area of research, a model was set up to clarify the effect of training on worker productivity.

\section{RESEARCH METHODOLOGY}

Research design is an frame work or plan for an analyst to answer research issues that is utilized to manage the technique and strategies of data collection and analysis.[18][19][21]

The current research is identified with Automobile Parts Industry. This defines the exploration unit of investigation among employees of Indian Automobile Parts Industry. The target population is defined as the total groups of specific population elements relevant to the research group.[22]

\section{A. SAMPLE}

In outlining out the sample, different issues should be engaged such as unit of investigation, population sampling strategies and sample size [22]. The respondents were selected on the comfort sampling design. Comfort sampling is utilized in research where the researcher is keen on getting a reasonable method of guaranteeing adequate quantities of the investigation [23] and roughly of reality [24].

\section{B. TOOLS FOR DATA COLLECTION}

To gather the necessary information for this investigation, both primary and secondary source of data was utilized. To gather primary data, close finished organized surveys were prepared. These surveys were then administered to the workers of automobile parts industry to collect data. Secondary data had been gathered from diaries, magazines, news articles, books, web and other archived material. Primary Data was collected through surveys (Questionnaire).

\section{QUESTIONNAIRE DESIGN}

Questionnaire is separated into 4 sections. First section incorporates demographic profile of respondents. In second segment training was concentrated with the assistance of 14 questions. In third area, inquiries on productivity were incorporated which likewise had 14 questions. The statements in second and third sections were of 5 point Likert scale to get the response of the respondents. The fourth area was open ended for communicating the respondents view.

\section{i. DEMOGRAPHIC DATA}

To examine the effect of training on worker's productivity the demographic details were gathered. Demographic factors incorporate gender, age, marital status, Educational Qualification, Grade, length of service, rating the training at the association, Training need assurance, Effective training technique.

\section{ii. INSTRUMENTS}

The accompanying instruments were used for the testing stage of study:

Feedback on Training: Questionnaire included different parts of training. A five-point scale where 5 is for Strongly Agree, 4 is for Agree, 3 is for Un Decided/Neutral, 2 is for D:s Agree and 1 is for Strongly Dis Agree, was utilized in the questionnaire to discover now much a training system impact worker.

Feedback on Productivity: Questionnaire included different parts of employee productivity improvement because of training. A five-point scale where 5 is for Strongly Agree, 4 is for Agree, 3 is for Un Decided/Neutral, 2 is for Dis Agree and 1 is for Strongly Dis Agree was utilized in the questionnaire to discover how much a training procedure impact on worker productivity.

\section{DATA COLLECTION METHOD}

Survey was considered for data assortment as it was an in superfluous choice, an overview is a method of gathering organized information through an example drawn from populace all together :o describe, clarify or investigate marvels [25][26][27]. Review are effective strategies in get-together information from a huge quantities of individuals [25][28]. These techniques have been broadly used to gather 


\section{International Journal of Engineering Applied Sciences and Technology, 2020 \\ Vol. 5, Issue 8, ISSN No. 2455-2143, Pages 97-101 \\ Published Online December 2020 in IJEAST (http://www.ijeast.com)}

quantitative and subjective information [26][29][30]. Overview are likewise physical vehicles for estimating mental factors, for example, assessment, perspectives, spaces and convictions [27] and can give bits of knowledge about easygoing clarifications. [21]

\section{E. TOOLS FOR DATA ANALYSIS}

The result of the overview was coded and taken care of in to the excel sheet. Subsequent to gathering and coding, data was prepared for statistical analysis. For analysis SPSS 20 statistical package was utilized. The sample characteristics of the dependent and independent factors just as the hypothesis produced by using the accompanying differing statistical techniques.
i. Reliability and validity test
ii. Descriptive Statistics
iii. Correlation examination
iv. Regression
v. ANOVA
vi. Student's T test

\section{RESEARCH METHODOLOGY}

The reason for training is to realize improvement in the presentation of work. It incorporates learning of such procedures as are required for better execution of unequivocal undertakings. Notwithstanding the way that worker training has no widespread acknowledged definition; its fundamental thought continues as before. The training begin with the gap investigation, at that point training need examination, training configuration, training conveyance, criticism, Evaluation and again training. The above writing has secured a large portion of the principle regions identified with trailing and employee productivity.

\section{REFERENCE}

[1] http://wevw.ibef.org/economy/indian-economyoverview,Last updated: Jul. 2015 (accessed on 27 Aug 2015 at 00.10 )

[2] Gome^-Mejia. R., et al (2007) Managing Human Resources 2nd edit on Pearson Education., New Jersey, USA

[3] Cole, G. A (2002). Personnel and Hunan Resource Management 5th edition York Publishers., Continuum London, UK.

[4] Cole, G. A. (2002), Personal and Human Resource Management, 5th ed. Continuum London: York Publishers

[5] Cascio, W.F (1989). Managing Human Resources 2nd edition McGraw Hill Book Company., New vork, USA.

[6] Linda Maund (2001) An Introduction to Human Resource Management, theory and practice, New York: Pelgrave Macmillan Publishers
[7] Cole, G. (2004). "Management Theory and Practice". 2nd edi. Bock Power London.

[8] Cole, G. A. (2004). Management Theory and Practice 6tn ed. Thornton Learning

[9] Monappa, A \& Saiyadain, M. (2008). Personnel Management 2nd ed. Tata McGraw-Hill, New Delhi.

[10] Bates, R \& Khasawneh, S 2005, Organizational learning culture, learning transfer climate and perceived innovation in Jordanian organizations 'International Journal of Training and Development, Vol. 9, no. 2, pp 96-109,

[11] Kenneth M. York (2009) Applied Human Resource Management Strategic Issues and Experiential Exercises PP186, SAGE Publications, Inc

[12] Afaq F et al, (2011), Employees' Training and Performance Relationship in Hospitality Sector A Case of Pearl Continental Hotel, Karachi, Pakistan, International Review of Business Research Papers Vol. 7.No. 3. May 2011. Pp. $49-158$

[13] Budria, S.; Pereira, P. (2008), The Contribution of Vocational Training to Employment, Job-Related Skills and Productivity: Evidence from Madeira Island, Discussion Paper series, IZA DP No. 3462, 1-35.

[14] Gupta, S., Bostrom, R.P. (2006): End-User Training Methods: What We Know, Need to Know. ACM.

[15] Sultana A., Irum S., Ahmed K., Mehmcod N. (2012), "impact of training on employee performance: a study of telecommunication sector in Pakistan", VOL 4, NO 6, Pp. 646-61.

[16] Omole, M. A. L. (2004): Training and re-training: A variable cf technological development. Journal of Industrial Education, 14 (2), pp. 76-85

[17] Nazimek J (2014), Exercise and brain power: how does physical activitv he ip us think? http://thebrainbank.sciencebiog. com/2014/10/12/exercise-and-bram-powerhow - doesphysical-activity-help-us-think/

[18] Bums, A.C. \& Bush, R. F. (1995). Marketing Research Englewood Cliffs, N J: Prentice Hal.

[19] Chu-chill, G.A. (1996). Marketing research: methodological foundations. New York: The Drvden Press.

[20] Ankita Shreeram $\left(20 \_1\right)$, The Just-in-Cme training http://www. i t srny asc ent.cotn/web/itsmyascent/hrzone/-'assetpublisher/4htH/ content/ the- just-in-timetraining

[21] Zikmund, WG (1997), Business Research Methods, Dryden Press, Fort Worth

[22] Zikmund,W.G. (2003).business research Methods (8th ed.).Cincirxiati. OH:Thomson/south western. 
[23] Black, T.R. (1999). Doing quantitative research in the social sciences: an integrate approach to research design, measurement, and statistics. London: Sage. 164

[24] McDaniel, C. and R. Gates (1991) Contemporary Marketing Research. St Paul, MN: West.

[25] Baobie, Earl. 1986.The Practice of Social Research, Belmont, California: Wadsworth Publishing Co.

[26] De Vaus, D. A. (2002). Surveys in Social Research, 5th Edition, Sydney

[27] Kerlinger, F.N. (1979). Behavioral research: A conceptual approach. New York: Holt, Rinehart, and Winston.

[28] Chadwick, B.A.,Bahr ,H.M.\& Albrecht ,S .L.(1984).Social Sciences Research Methods Englewood Cliffs ,NJ :Prentice Hall

[29] Hussey, J. Hussey, R. (1997.) Business research - A practical guide for undergraduate and postgraduate students Londen Macmillan Business.

[30] Neuman, W. L. (2003). Social research methods Qualitative and quantitative approaches (6th ed.). Boston: Allyn and Bacon. 